Prof. Josef Luchko ${ }^{\left.1)^{*}\right)}$

Ph. D. Eng. Yaroslav Bolzhelarskyi ${ }^{1)}$

M. Sc: Eng. Vitalii Kovalchuk ${ }^{1)}$

Ph. D. Eng. Mykola Sysyn ${ }^{2}$

\title{
Research of derailed wheelset impact marks on the concrete sleepers
}

\section{Badania uszkodzeń podkładów kolejowych w wyniku wykolejenia}

DOI: $10.15199 / 33.2016 .11 .08$

Abstract. The process of destruction of reinforced concrete deepers under the railway wheel impact loading is being studied, The article proposes the impact test method of sleepers using a pendulum impact machine. It was developed a device to measure the parameters of impact marks. Using the proposed device it was analyzed the form of the impact marks left by the railway wheel.

Keywords: wheelset, reinforced concrete sleepers, track, derailment, profilograph, measurement
(Oryginalny artykuł naukowy)

Streszczenie. W artykule przeanalizowano charakter uszkodzenia żelbetowych podkładów kolejowych poddanych działaniu dynamicznego obciążenia udarowego od kół taboru kolejowego (na bazie badań z użyciem kafara wahadłowego). Przeprowadzono badania laboratoryjne żelbetowych podkładów kolejowych aż do zniszczenia. Opracowano urządzenie do pomiaru geometrycznych parametrów śladu uderzeń koła pociągu.

Slowa kluezowe: zestaw kołowy, żelbetowe podkłady, ślad, wykolejenie, profilograf, pomiar.
The rolling stock derailments followed by the movement of derailed wheelset along the track panel leaving characteristic marks on the surface of reinforced concrete sleepers often take place at the Ukrainian railways. At this, the train movement resistance affecting the results of traction calculations, which take place during investigation of railway accident is increased $[2,7]$.

The methodology of determining the additional train movement resistance caused by the wheelset movement along the track panel is currently under development [1]. One of the components of this movement resistance is the impact resistance and the following wheel rolling along reinforced concrete sleepers. The value of this resistance is equivalent to the energy absorbed by the sleeper and should be connected with the pameters of the marks left on the sleepers. The destruction of reinforced concrete sleeper is a stochastic process; after the wheel impact on the sleeper surface there appear irregularities of different forms and depths.

One of the methods to study the reinforced concrete sleepers is the impact loading lest $[3,4]$. During the test various types of impact machines are used. They make it possible to determine the energy with which the striker affects the sleeper. Using

Dnipropetrovsk National University of Railway Transport named after Academician V. Lazaryan, Lviv Branch

Technische Universität Dresden, Fakultät Verkehrswissenschaften „Friedrich List”

"Adres do korespondencji: luchko.diit@mail.ru such impact machines it is possible to simulate the actual processes taking place in the railway track with no need for experiments on the track.

\section{Design of measuring device (profilograph)}

To measure the parameters of the impact marks it was designed and manufactured the profilograph. The operation of the device is based on the destruction surface scanning by the laser beam, its position on the destruction surface is fixed by high-resolution digital camera. As a result of the scanning the spatial position of surface points of the destruction surface is obtained.

\section{Scanning the surface of impact mark}

Before scanning it is measured the length of the mark formed on the reinforced concrete sleeper. It determines the maximum distance of the laser and camera movement that defines the number of scanning steps. Commands from the PC to the stepper motor are transmitted through the microcontroller programmed in Matlab 10.0. According to the commands the stepper motor moves laser and camera along the horizontal guide bar at the given distance, as a result of this it is shott he profile surface of the impact mark with the given step of the camera and laser movement. The camera records the graphic representation of the laser beam on the surface of the mark (Photo 1).
Using the developed software according to the developed algorithms for automatic recognition and measurement of bitmap images it is determined the parameters of scanned laser trail on the surface of sleeper that are transferred to the computer memory and displayed on the monitor. After measuring the cross-section of the impact mark surface of the sleeper in the given number of steps of longitudinal movement of measuring system, the results of individual measurements are connected and the mathematical model of the impact mark surface is being formed (Figure).

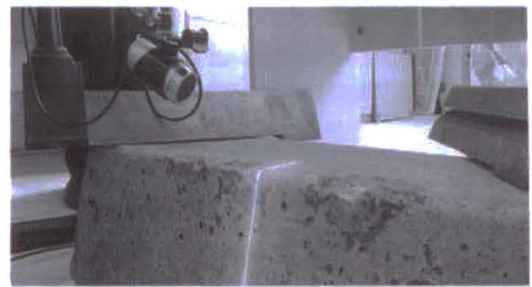

Photo 1. Scanning the surface of reinforced concrete sleeper

Fot. I. Skanowanie powierzchni podkladu kolejowego

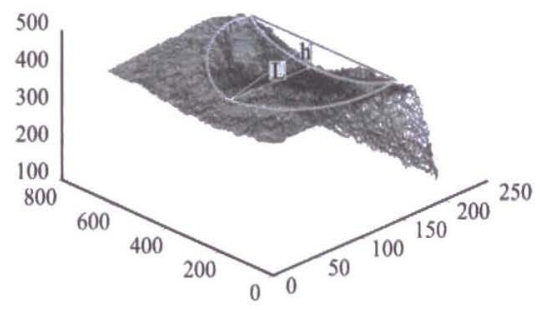

Surface of the impact mark on the reinforced concrete sleeper

Powierzchnia śladu uderzenia na żelbetowym podktadzie kolejб̄wym 


\section{The process of laboratory tests of the sleeper}

For testing the reinforced concrete sleepers the pendulum impact machine with experimental striker was used (Photo 1). The experimental striker is made of standard striker of the given impact machine. The part of the railway wheel was attached to the striker in such a way that when one installs it in the impact machine, the sleeper would impacted by the tip of the wheel flange.

Ten test samples were cut for research from the middle part of reinforced concrete sleepers of the type SH-1-1. The samples were installed in the impact machine so that the direction of the impact of striker coincided with the direction of railway wheel impact when moving along the track panel.

Each sample was tested three times - from the lift height of the mass center of the striker over the impact site $0.36 ; 0.93$; $1.52 \mathrm{~m}$. The striker with the weight $500 \mathrm{~N}$ developed the energy $180 ; 465 ; 720 \mathrm{~J}$ correspondingly.

As a result of the impact there remained the characteristic marks on the sleeper, with a certain depth in the direction of the impact $h_{c}$, length along the edge of the sleeper $l_{c}$, the maximum width along the upper and lateral $b_{c}$ edges of the sleeper and the volume of material that was broken off $\mathrm{V}_{\mathrm{e}}$ (Photo 2).

Using the developed software, the mentioned parameters of the mark were determined automatically. The obtained value of linear parameters $\left(h_{c}, 1_{c}, a_{c}, b_{c}\right)$ were tested by measuring with caliper. The softwa-

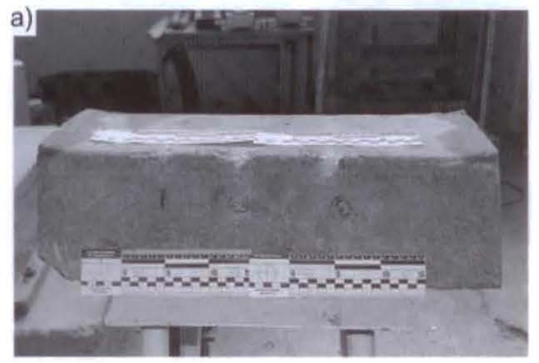

b)

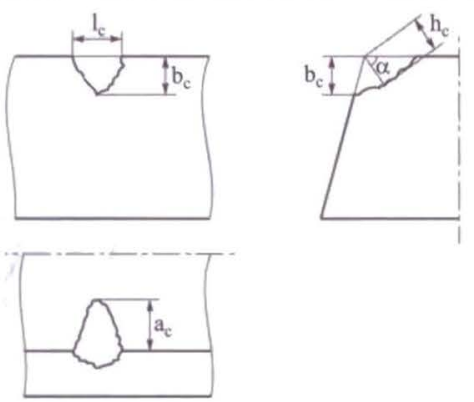

Photo 2. Impact marks (a) and their parameters (b)

Fot. 2. Ślady uderzeń (a) $i$ ich parametry (b) re calculation of the volume was tested as follows: each site of the impact was filled with plastic material, it was reproduced the sleeper form and the plastic material after separation from the sleeper was placed in a graduated cylinder filled with water.

Laboratory tests of mechanical properties of building materials are a classic case of discrete random variable, which is subjected to the normal law of distribution $[5,6]$. In this regard, the experimental data are tested for the conformity to normal law of distribution by the Pearson criterion.

The results of the parameters check $h_{c}$, $l_{c}, a_{c}, b_{c}, V_{c}$ for the conformity to the normal law of distribution are summarized in the Table. The same Table presents the results of calculation of the energy absorbed by the sleeper and the average value of the parameter $\bar{y}$. In the Table the values $\chi^{2}$ for the significance level 0.9 and more are shown in bold.

Summary results of the parameters inspection for compliance with the normal distribution law

Podsumowanie wyników badania w zgodności z prawem rozkladu normalnego

\begin{tabular}{|c|c|c|c|c|}
\hline Parameter & H & E & $y \cdot 10^{-3}$ & $\chi^{2}$ \\
\hline \multirow{3}{*}{$h_{c}$} & 0,36 & 180 & 7,72 & 0,196 \\
\hline & 0,93 & 465 & 10,61 & 0,117 \\
\hline & 1,52 & 760 & 12,99 & 0,196 \\
\hline & 0,36 & 180 & 34,73 & 0,044 \\
\hline & 0,93 & 465 & 51,01 & 0,177 \\
\hline & 1,52 & 760 & 55,91 & 0,148 \\
\hline \multirow{3}{*}{$a_{s}$} & 0,36 & 180 & 18,85 & 0,474 \\
\hline & 0,93 & 465 & 30,44 & 0,392 \\
\hline & 1,52 & 760 & 37,65 & 0,165 \\
\hline \multirow{3}{*}{$b_{c}$} & 0,36 & 180 & 26,59 & 0,403 \\
\hline & 0,93 & 465 & 28,25 & 0,355 \\
\hline & 1,52 & 760 & 33,48 & 0,227 \\
\hline \multirow{3}{*}{$V_{e}$} & 0,36 & 180 & 2,87 & 0,148 \\
\hline & 0,93 & 465 & 6,31 & 0,408 \\
\hline & 1,52 & 760 & 9,54 & 0,823 \\
\hline
\end{tabular}

As it is shown in the Table, for the parameter $h_{c}$ (the depth of the mark in the direction of impact) and the parameter $l_{c}$ (the length of the mark along the edge of the sleeper) the check for normal law of distribution is carried out at the level of significance 0.9 for all values of the energy absorbed by the sleeper. Therefore, these parameters should be taken as signs in determining the value of the energy absorbed by the sleeper.

\section{Conclusions}

The device and methodology of the mark measurements left by the railway wheel flange during the impact with sleeper were developed in the research. It was carried out the experiment, in whic the sleeper was subjected to impact loadin equivalent to the loading, which affects th sleeper when the derailed railway whe is moving along the track panel. With th developed device, the algorithm an software the impact mark parameters we measured. The measurement results at checked by traditional measuring tools.

During the research statistical processin of the measurement results of geometric py rameters of the mark and their check fi compliance with the normal law of distrib tion were conducted. It was found that th distribution of values of the mark depth mo asured in the direction of the impact $h_{c}$ an the width of the mark a long the edge of th sleeper $l_{\mathrm{c}}$ corresponds to the normal law o distribution with a significance level $\alpha>0$. As the evaluation criterion of the energ value absorbed by the sleeper it recommended to use the parameter $h_{c}$, that with the smaller variation of values.

The directions for future research includ improving the device design to make, possible to use it for the measurement directly on the railway track.

\section{References}

[1] Bodnar B., Ya. Bolzhelarskyi, I. Laushnyk. 201f „Mathematical model of the derailed train whe motion”. VIII International Conference. Transpo Problems pp. 60-69. [in English].

[2] Bolzhelarskyi Ya. V. 2016. „Nablyzhene vyzn chennia dodatkovoho oporu rukhu poizda $\mathrm{v}$ avan nomu rezhymi. konferentsii" Problemy mekhamil zaliznychnoho transportu. [Approximate determ] nation of the additional train movement resistano in the emergency mode. Conference „Problems Railway Transport Mechanics"]. Dnipropetrovs' pp. 24-25. [in Ukrainian].

[3] Esmaeili M., S. A. S. Hosseini, M. Sharavi. 2016 Experimental assessment of dynamic lateral resistan ce of railwayconcrete sleeper. Soil Dynamics an Earthquake Engineering 82: 40-45. [in English].

[4] Kaewunruen S., A. M. Remennikov. 2011 „Experiments into impact behaviour of railway pro stressedconcrete sleepers". Engineering Failun Analysis 18: 2305-2315. [in English].

[5] Luchko Y. Y., Ye. H. Ivanyk. 2010. Systemm] analiz protsedury obroblennia eksperymentalnyk danykh vyprobuvan mashynobudivnykh ta budive nykh materialiv $i$ konstruktsii [System analysis o processing procedure for experimental data of to sting the engineering and building materials an structures]. Kameniar. Lviv. [in Ukrainian].

[6] Luchko Y. Y., O. S. Raspopov. 2014. Budiveln mekhanika sterzhnevykh system [Structural mechs nics of bar systems]. Kameniar. Lviv. [in Ukrainian] [7] Sokol E. N. 2007. Krusheniya zheleznodorozhnyks poyezdov (Sudebnaya ekspertiza. Elementy teori ipraktiki) [Train accidents (Forensic Science. Elements of theory and practice)]. Kyiv: Feniks. [in Russian].

Przyjęto do druku: 27.09.2016r 